RESEARCH ARTICLE

\title{
Sex Gratification in Indonesian Anti-Corruption Law: What is the Problem?
}

\author{
Hesty Dian Yustikarini \\ Semarang Society for Indonesian Better Future \\ JI. Taman Siswa, Sekaran, Gunungpati Semarang, INDONESIA \\ 凶hestydian@gmail.com
}

\section{อ OPEN ACCESS}

Citation: Yustikarini, H. D. (2021). Sex Gratification in Indonesian Anti-Corruption Law: What is the Problem?. Law Research Review

Quarterly, 7(4), 505-514. https://doi.org/10.15294/Irrq.v $7 \mathrm{i} 4.48174$

Submitted : June 9, 2021

Revised : October 12, 2021

Accepted : November 1, 2021

(C) The Author(s)

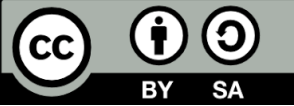

This work is licensed under a Creative Commons Attribution-ShareAlike 4.0 International License. All writings published in this journal are personal views of the authors and do not represent the views of this journal and the author's affiliated institutions.

\section{ISSN 2716-3415}

Law Research Review Quarterly published by Faculty of Law, Universitas Negeri Semarang, Indonesia. Published quarterly on February, May, August, and November.

\section{Abstract}

The phenomenon of prostitution in Indonesia has become a negative spectre that refers to its dilapidated moral society. This polemic is one of several different dimensions. Stewardship is also felt because law enforcement is not entirely. Prostitution as a name given to indicate the act in which a woman sends herself to relate to the opposite sex in need of money or other forms of payment. Inspired by the rampant sexual gratification cases among state officials. Ratification process and goods but sadness gratification in expanding sexual section. Added the sexy offender (female) underage. Previously gratification is already in Law Number 20 Year 2001 on Corruption Eradication in article $12 \mathrm{~B}$, but not yet directly in the scope of sex gratification. Thus, there needs to be a legal reform synchronized with the rules and protection of human rights for working women. Until now the sexy gratification case is still taboo because it is considered apathetical State has not been possible to do and provide a deterrent effect for service providers, separation and distribution for the perpetrators of sexual. This is the polemic that must be emphasized from the rising.

Keywords: Sex Gratification; Anti-Corruption; Policy

\section{INTRODUCTION}

Gratification Sex among state officials who are contrary to moral values. Gratuities are defined as giving money to employees outside of the right salary. The term gratification itself is derived from Dutch, gratifikatie which is 
then adopted into a word in English which means a gift. The term gratification in English called gratification is a term that appears in the Anglo-Saxon countries and continental Europe. The term gratification arises because of the difficulty of proving oral bribery, the previous gratification is more known as a gift or a favor. Gratuities are often identified with the form of money. However, there is currently a practice of Sexual Gratification in which the perpetrators come from among the people or in countries that are currently being warmly discussed. The current Gratification Sex provisions still apply, as there is no provision on Sex Gratification that is very important and very heavy for women's performance. This is why some of the Gratification Sex practices are still rampant and difficult to follow up. Thus, many Gratified Sex offenders are separated from the bondage of law and care to repeat it.

This is the background of this. In addition, these practices are contrary to the values in society and also because there are things that lie behind the granting of gratuities. So, it needed Required Functions to cope with the phenomenon. Various kinds and provisions of legal law that have a purpose, namely for the welfare of humans in everyday life. One way to achieve awareness is that the State is reforming, and people are always doing development. Based on that law must constantly make updates, so that the purpose of the law can unite with the sense of community's authenticity.

\section{RESULT AND DISCUSSION}

\section{A. Sex Gratification as Part of Human Rights}

Human rights are the rights inhabited by human beings without exception and privileges for certain groups, groups, and social levels of human beings. These rights are the right to life, safety, liberty, mind, and them from all forms of oppression that must be upheld, cannot by any individual of the states recognized and enjoyed by itself, but must also be guaranteed by the State without any 
exceptions. Women are groups within societies within countries that are also responsible for their rights as a whole. Violations of the human rights of women are also considered to be a violation of the general human rights. So far, the issue of women's human rights as part of human rights is still an issue that has not been popularized yet. It is even a marginal issue among other human rights issues such as civil, political, economic, social, and cultural rights. The case of Gratification Sex arising among State officials becomes a big question that should be investigated and prosecuted in accordance with the violent act. It is very sad if women become morality games only when women are a group that should be considered the specificity of human rights in this case it is natural for women to be protected their rights and self-esteem. Especially if the perpetrators of sexual is underage women who should float wings to a more glorious future. It is as if the right is simply snatched away.

Criminalization of this case must be comprehensive to the criminal what naturally obtained by service users (officials), the intermediary (officials), and the perpetrator sexual (female). In this case it is clear that human rights have covered the case of sexual gratification into something to be accounted for. Not only covered by Corruption alone but on the other hand there are women underage who became sex offenders injured Human Rights. Actually, has many legal theories that presents because of the phenomenon of injustice in society. One of them that highlights the legal game that is felt to give too much partiality to some groups only. One that highlights the existence of injustice which highlights the existence of injustice in the implementation of law and questioning the neutrality of law is the Theory of Feminist Law. This theory reinforces the aspects of anything which then emphasize the right of rights that must be felt especially the women's group, some feminist ideas have begun to discuss and highlight the phenomena that occur related to the role and social status of women in society. 
Thus, it is clear that the arrangements and theories are meant more to regulate the morality of a woman. But on the contrary, in reality the rules are contradictory. In this case it appears that the custom rules of law view women (victims) solely as regulatory objects not a legal subject that needs to be protected. Given the fact that legal theory contains something that describes the general character of the law rather than from a particular point of view. The law itself is not neutral and the fact that law can be used by experienced people only while weak creatures such as women will be destined to remain below. Therefore, it is necessary to study human rights and justice in Indonesia to make representation or new meaning of existing regulation so that new understanding can be applied to be applied in case of violence against woman more justly.

\section{B. Law Arrangement and Renewal of Gratification Sex Cases}

The regulation on Gratification in Indonesia is regulated in a separate law outside the Criminal Code, in Law Number 20 Year 2001 concerning the Eradication of Corruption (Corruption), namely Article 12 B Paragraph (1), "A civil servant or an organizer of a country receiving a prize, whereas it is known or reasonably suspected that the prize is awarded as a result or is due to having done or not to do something in his / her position against his / her obligations".

The Act does not explicitly mention that gratification can be done by providing sexual services and calling Sex Gratification as one form of gratification that can be prosecuted legally. Thus, the current Corruption Act is considered inadequate because it has not been able to regulate in detail all aspects of Gratification Sex, in which case there is still a void of norms. According to Article 1 paragraph (3) of the 1945 Constitution of the Republic of Indonesia that Indonesia is a State of law, where it is important that there is a rule as a tool of law enforcement in Indonesia. 
There is no regulation on Gratification of Sex, which regulates it specifically in a legislation in Indonesia. However, if it is more studied it is very necessary for the rule of law that is more specific to the crime Gratification Sex. Regarding the gap of norms that occur on the crime Gratification Sex is very necessary a special rule that can manage thoroughly and detailed and able to manage all aspects of Gratification Sex. The regulation of violent crime in the Act is intended to regulate the morality of a person and not to protect the woman who is the victim of the gratification sex case. In this case it appears that the legal rules view women as casualties only as regulatory objects and are not subject to legal protection. Because there is no specific regulatory regulation but on the other hand there is a provisioning article on protection for the offender (underage women).

Associated with the woman is a woman under the age then by nature can be protected which is then regulated in child abuse law, Article 287 of the Criminal Code: "Anyone who has intercourse with a woman outside of marriage, knowing it or should be suspected that she is not yet fifteen years of age, or age is not clear, that she is not yet time to be married, threatened with a maximum of nine years imprisonment". Whereas in Law No. 23 Year 2002 on Child Protection, there are two articles that regulate the threat of punishment for perpetrators of sexual abuse of minors, namely article 81 and article 82 .

1) Article 81 which reads:

"Any person who deliberately violates or threatens violence to force a child to have sexual intercourse with him or another person shall be punished with a maximum imprisonment of 15 (fifteen) years and a minimum of 3 (three) years and a maximum fine of Rp.300. 000. 000, 00 (three hundred million rupiah) and at least Rp. 60,000,000.00 (sixty million rupiah). "

2) Article 82 which reads:

"Anyone who deliberately perpetrates violence or threats of violence, forces, tricks, a series of lies, or 
persuades a child to commit or allow obscenity to be punished by a maximum imprisonment of 15 (fifteen) years and a minimum of 3 (three) year and a maximum fine of Rp.300. 000. 000, 00 (three hundred million rupiah) and at least Rp. 60. 000. 000, 00 (sixty million rupiah). "

Furthermore, it is also emphasized that, "The Criminal Code Draft is contained in the chapter on Criminal Acts in covering 56 Articles (467-504), divided into ten parts, such as: the violation of morality itself, pornographic and porno action, rape, adultery and lewd acts (starting crime for couples who live together without "legitimate marriage" ties to intercourse with children), trafficking for prostitution, animal abuse, pregnancy prevention, matters relating to abortion, begging, intoxicating ingredients to gambling."

From the exposition of the articles on penalties for the perpetrators of sexual abuse of minors mentioned above, it can be concluded that the punishment for the perpetrator varies, the criminal act of sexual harassment committed by a person against another person who is not his wife is a complaint offense which means that only the victims can feel it and have more right to make a complaint to the authorities to handle the case. In implementing the reform of the national law should be oriented to the balance of social and social welfare, so there is a balance between the values that live in society and the values that apply universally.

Likewise, in the development of criminal law, the development of criminal law can be done through the construction of law in the form of criminal law policy through the formulation / legislation process, and law enforce cement, namely the application / judicial (execution) and execution process. In legal conspiracy as a means of development and renewal, the law plays a role as legal rules or rules that serve as regulator / means of development, especially in regulating the flow of human activities towards the desired development or renewal. The law will always be necessary in every process of change in a developing society. 
Therefore, in order for development and change to run orderly, then there must be a means to regulate it. This is where the law is desired by development and absolutely must be put into effect. Development and renewal are a revolution that can run sooner or later, depending on the wishes of the people and the policies of the government, thereby creating the desired or unwanted effects. Unintended impacts will cause difficulties or even chaos. Therefore, the means that can control it is through the legal system which one of them can be realized in legislation.

\section{Criminal Policies and Penalties on Gratification Sex Cases}

According to Simons quoted from the book E. Utrecht formulates strictab feit or offense as "an act which by law is threatened with criminal, contrary to law, done by a guilty person and the person is held responsible for his actions." Gratification in this case is an act criminal. Gratification such as construction in Articles 12 B and 12 C of Law Number 20 Year 2001 on Corruption Eradication is considered a criminal act, in this case equal to a bribe, in relation to the position and which is contrary to its obligations or duties. Strictly speaking, if the gratification is not related to office and that is contrary to its obligations or duties, the gratuity is a legal act.

The perpetrator of the Criminal Act of Corruption "Gratification Sex", both the actor or the beneficiary of Gratification Sex can be charged or charged with Article 5 jo. Article 12 letter a and letter b Law No. 20 of 2001 on Amendment to Law no. 31 of 1999 on the Eradication of Corruption (Corruption Law) namely a fine of at least Rp $50,000,000.00$ (fifty million rupiah) and a maximum of Rp 250,000,000.00 (two hundred and fifty million rupiah). stipulates the sanction provisions of the grantor and receiver of the gratuities but does not yet contain the provisions of sanctions against the female perpetrators of their services. In the sense of need to apply legal sanctions for women 
providing sexual services, because he is categorized as a participant in the crime Gratification Sex that has participated in supporting and damaging the image of this nation. But sadly, sex service providers are women under the age of the naturally entitled to be protected not a criminal. Being a polemic indeed, but it is clear to the bribed and bribed offender getting the bondage under the protection law for the underage perpetrator.

\section{CONCLUSION}

This study concluded that gratification sex needs to be specially created rules that are able to manage thoroughly and in detail. To address all necessary social concerns and sensitivities, both from the stakeholders (government), the authorities (law enforcement) and all walks of life within the community. In addition, the development of the legal system must also be able to balance it, so that people's lives can run harmoniously and synergy in social life. The arrangement of sex gratification in the perspective of criminal law based on corruption criminal law is basically for when there is no clear regulation to be taken as a legal basis, so that in the case of gratification sex is still included in the criminal act of gratification in general only the form of the gift different so for now it cannot be said that the gratification or gift in the form of sex services is said to be a crime of gratification of sex. The inhibiting factor in the proof of sexual gratification in the perspective of criminal law based on corruption law is basically a legal factor, a legal factor relating to a factor of law where the enforcement apparatus, especially the Prosecutor and Judge in this case, has no regulation and evidentiary system strong governing the issue of sexual gratification.

\section{DECLARATION OF CONFLICTING INTERESTS}

The Author declares that there is no potential conflict of interest in the research, authorship, and/or publication of this article. 


\section{FUNDING}

None

\section{ACKNOWLEDGEMENT}

None

\section{REFERENCES}

Darwan, P. (2002). Pemberantasan Tindak Pidana Korupsi. Bandung: Aditya Bakti.

Henny, N. (2018). Crime of Trafficking in Persons (Criminal Law Policy and Prevention). Jakarta: Sinar Grafika.

Mahrus, A. (2012). Criminal Law Basics. Jakarta: Sinar Grafika.

Nawawi, B. A. (2019). Corruption and Law Enforcement Efforts (Kapita Selekta). Jakarta: PT. Adika Remaja Indonesia.

Niken, S. (2019). Women's Rights Criticism Theory of Feminist Law Against the Criminal Code. Bandung: PT Refika Aditama.

Satjipto, R. (1991). Ilmu Hukum. Jakarta: Citra Aditya Bakti. 
Together with a culture of work, there must be a

culture of leisure as gratification. To put it another way: people who work must take the time to relax, to be with their families, to enjoy themselves, read, listen to music, play a sport.

Pope Francis 